\title{
Randomised double blind study of hypotonic oral rehydration solution in diarrhoea
}

Tarja Rautanen, Seija Kurki, Timo Vesikari

\begin{abstract}
A hypotonic (osmolality $224 \mathrm{mmol} / 1$, sodium $60 \mathrm{mmol} / \mathrm{l}$ ) oral rehydration solution (ORS) was compared with an isotonic high glucose ORS (osmolality $304 \mathrm{mmol} / 1$, sodium $60 \mathrm{mmol} / \mathrm{l}$ ) in children with acute diarrhoea in a randomised double blind study. The stool output and hence the mean consumption of ORS for maintenance hydration was less $(p=0.036)$ in patients receiving hypotonic $(69 \mathrm{ml} / \mathrm{kg})$ than isotonic $(97 \mathrm{ml} / \mathrm{kg})$ ORS. Hypotonic ORS was more effective in patients with rotavirus positive than with rotavirus negative diarrhoea.

(Arch Dis Child 1997;76:272-274)
\end{abstract}

Keywords: oral rehydration therapy; diarrhoea; osmolarity; rotavirus.

Oral rehydration therapy has become widely accepted in developed countries, but unlike in developing countries, oral rehydration solutions (ORS) usually have a low sodium concentration of $60 \mathrm{mmol} / \mathrm{l}$ or less but a high glucose concentration, and the solutions are either isotonic or slightly hypertonic. ${ }^{12}$

Studies in animal models and human volunteers have shown that the osmolarity of ORS may be a critical factor influencing absorption of water and electrolytes from the small intestine.$^{3-6}$ Hypotonic solutions with osmolarity of $200-250 \mathrm{mmol} / 1$ perform better than hypertonic or isotonic solutions. Farthing concluded from experimental studies that a sodium concentration around $60 \mathrm{mmol} / 1$ and glucose between 50 and $100 \mathrm{mmol} / \mathrm{l}$ are optimal for absorption of water. ${ }^{5}$

We previously tested a reduced osmolarity (224 mmol/l; glucose $84 \mathrm{mmol} / 1$, sodium 60 $\mathrm{mmol} / \mathrm{l})$ ORS in an open trial in paediatric diarrhoea and found that this ORS performed better than a high glucose isotonic ORS with the same sodium concentration. ${ }^{7}$ We have now repeated the study in a randomised double blind trial in another hospital.

Finland

T Rautanen

S Kurki

University of Tampere Medical School, Tampere, Finland $\mathrm{T}$ Vesikari

Correspondence to: Professor Timo Vesikari, University of Tampere, Medical School, PO Box 607, FIN-33101 Tampere, Finland.

Accepted 19 November 1996

\section{Methods}

The study protocol was approved by the ethics review committee of the Jorvi Hospital. Informed parental consent was obtained for all patients enrolled in the study.

The study was carried out between 25 May 1992 and 8 June 1993 at the Jorvi Hospital, Espoo, Finland. Infants aged less than 36 months admitted for acute diarrhoea with duration of five days or less were enrolled in the study.
Table 1 Composition of the oral rehydration solutions (ORS) (mmol/l) used in the study

\begin{tabular}{lll}
\hline & Hypotonic ORS & Standard ORS \\
\hline Sodium & 60 & 60 \\
Potassium & 20 & 20 \\
Chloride & 50 & 50 \\
Glucose & 84 & 144 \\
Citrate & 10 & - \\
Bicarbonate & - & 30 \\
Total osmolarity & 224 & 304 \\
\hline
\end{tabular}

Patients were randomised to receive either a reduced osmolarity ORS $(224 \mathrm{mmol} / \mathrm{l})$ or the standard ORS (304 mmol/l) then used in Finland. The reduction of osmolarity was mainly achieved by reducing the amount of glucose from 144 to $84 \mathrm{mmol} / 1$ in the hypotonic solution. In addition, the standard ORS contained bicarbonate instead of citrate. The molar compositions of the two solutions are shown in table 1 . The dry powder to prepare $500 \mathrm{ml}$ of either ORS was packaged in paper bags, which were letter coded from A to F, with three letters for each ORS. The assignment of patients to receive either ORS was done according to a computer generated randomisation list.

On admission, the physician on duty examined the patient and estimated the degree of dehydration. The amount of ORS was prescribed according to the degree of dehydration. The recommendation was to give four thirds of the estimated fluid deficit during the first six to eight hours. The slight overcorrection of dehydration was to ensure success in rehydration despite of vomiting, ongoing stool losses, and difficulties in accepting the drink. A nasogastric drip was used if necessary. After the initial rehydration, maintenance hydration was prescribed according to the stool output, approximately $100 \mathrm{ml}$ per diarrhoeal stool for children below 2 years of age and $200 \mathrm{ml}$ per diarrhoeal stool for older children, with a minimum of 30 $\mathrm{ml} / \mathrm{kg} /$ day if diarrhoea continued. For continued vomiting the physician in the ward estimated the need of ORS. Normal feeding for age was resumed after the initial rehydration period.

The exact amount of ORS given and stools passed were recorded by nurses. Weight was taken on admission, after initial rehydration, and daily thereafter until discharge. Blood sodium, potassium, and acid-base balance were determined on admission and daily thereafter during the hospital stay. Urine samples for sodium and osmolarity determination were collected from male patients in the morning after initial rehydration. A stool sample was taken during the hospital stay for the detection 
Table 2 Characteristics on admission and initial rehydration of patients with diarrhoea receiving reduced osmolarity oral rehydration solutions (ORS) and standard ORS; values are mean ( $95 \%$ confidence interval)

\begin{tabular}{|c|c|c|}
\hline & $\begin{array}{l}\text { Hypotonic ORS } \\
(n=35)\end{array}$ & $\begin{array}{l}\text { Standard ORS } \\
(n=35)\end{array}$ \\
\hline Age (months) & $16.2(14.3$ to 18.1$)$ & 15.7 (13.4 to 18.0$)$ \\
\hline Duration of diarrhoea before admission (hours) & $59.7(52.0$ to 67.4$)$ & $57.4(47.7$ to 67.1$)$ \\
\hline Acute weight loss (g) & 469 (392 to 546$)$ & $444(368$ to 520$)$ \\
\hline Base deficit on admission $(\mathrm{mmol} / \mathrm{l})$ & $-8.5(-7.2$ to 9.8$)$ & $-9.1(-8.1$ to 10.2$)$ \\
\hline Amount of ORS in first $6-8$ hours $(\mathrm{ml})$ & $634(578$ to 690$)$ & $601(532$ to 670$)$ \\
\hline $\begin{array}{l}\text { Ratio of body weight change to the admission } \\
\text { weight }(\%)\end{array}$ & $+2.6(1.9$ to 3.3$)$ & $+3.0(2.5$ to 3.5$)$ \\
\hline
\end{tabular}

Table 3 Outcome of patients with diarrhoea receiving reduced osmolarity ORS and standard oral rehydration solutions (ORS) (mean ( $95 \%$ CI) or median (min-max))

\begin{tabular}{|c|c|c|}
\hline & $\begin{array}{l}\text { Hypotonic ORS } \\
(n=35)\end{array}$ & $\begin{array}{l}\text { Standard ORS } \\
(n=35)\end{array}$ \\
\hline $\begin{array}{l}\text { Mean amount of ORS during maintenance } \\
(\mathrm{ml} / \mathrm{kg})\end{array}$ & 69.2 (52.4 to 85.9$)$ & $96.5(77.5$ to 115.5$)$ \\
\hline $\begin{array}{l}\text { Median number of diarrhoeal stools in hospital } \\
\text { (min-max) }\end{array}$ & $7.0(1$ to 52$)$ & $13.0(1$ to 79$) \dagger$ \\
\hline Mean duration of diarrhoea in hospital (hours) & $44.9(37.8$ to 52.1$)$ & $54.4(45.6$ to 63.2$)$ \\
\hline
\end{tabular}

of rotavirus and adenovirus using latex agglutination tests (Orion Diagnostica, Espoo, Finland).

All data were analysed using standard statistical methods. The two tailed Student's $t$ test, the Mann-Whitney U test, and the $\chi^{2}$ test were used.

\section{Results}

Initially 82 children met the inclusion criteria but only 70 patients were included; 12 patients who did not pass any diarrhoeal stools in the hospital and therefore did not receive maintenance therapy after initial rehydration were excluded from the analysis. Of the 70 patients, $40(57 \%)$ were positive for rotavirus and two were positive for adenovirus. Stool cultures for bacteria were taken in four cases; all were negative.

The 70 children included in the study were equally divided between recipients of hypotonic and standard ORS. On admission, the two groups were comparable for age, duration of diarrhoea, degree of dehydration, and acidosis (table 2). The amount of ORS given for initial rehydration was nearly the same in the two groups. This was expected, as the mean acute weight loss in the two groups was similar. There was no difference between the groups in weight gain after initial rehydration (table 2).

The amount of ORS given for maintenance therapy was different in the two groups (table 3). The mean consumption of maintenance fluid per body weight (admission weight) was $69.2 \mathrm{ml} / \mathrm{kg}$ in the hypotonic ORS group and $96.5 \mathrm{ml} / \mathrm{kg}$ in the standard ORS group $(\mathrm{p}=$ 0.036 ). There was no difference between the two groups in weight gain by discharge.

The median number of diarrhoeal stools passed during hospital stay was smaller in the hypotonic ORS group (7.0 stools) than in the standard ORS group (13.0 stools) ( $\mathrm{p}=0.037$, Mann-Whitney $U$ test, table 3). The mean duration of diarrhoea in hospital was shorter in the hypotonic than in the standard ORS group, but the difference was not significant ( $\mathrm{p}=$ 0.102 , table 3).

There were no differences between the groups in the electrolyte balance and in the recovery from acidosis during the hospital stay. Also, urine sodium and urine osmolarity after rehydration were similar in the two groups. Three patients in the hypotonic ORS group and two in the standard ORS group required intravenous fluids besides oral therapy (difference not significant).

\section{Discussion}

In our previous open study, a hypotonic ORS (sodium $60 \mathrm{mmol} / \mathrm{l}$, glucose $84 \mathrm{mmol} / \mathrm{l}$ ) was superior to an ORS with the same sodium but a higher glucose concentration $(144 \mathrm{mmol} / \mathrm{l})$. The number of diarrhoeal stools was significantly smaller in the recipients of the hypotonic ORS, as was the duration of diarrhoea and the consumption of maintenance fluid. ${ }^{7}$

In the present double blind study the sample size was smaller but the results were very similar. In this study the number of diarrhoeal stools and consumption of maintenance fluid were significantly decreased, and a trend towards shorter duration of diarrhoea was seen.

Superior absorption properties of reduced osmolarity ORS have been found in comparative studies with the ORS recommended by the World Health Organisation (WHO) (osmolarity $311 \mathrm{mmol} / 1$, sodium $90 \mathrm{mmol} / 1$, glucose 111 $\mathrm{mmol} / \mathrm{l}$ ), conducted in Egypt (reduced osmolarity ORS contained sodium $60 \mathrm{mmol} / 1$ and glucose $75 \mathrm{mmol} / \mathrm{l}$, with osmolarity of 210 $\mathrm{mmol} / \mathrm{l}$ ), and in a multicentre evaluation in Brazil, India, Mexico, and Peru (sodium 60 $\mathrm{mmol} / \mathrm{l}$, glucose $84 \mathrm{mmol} / \mathrm{l}$, and osmolarity 224 $\mathrm{mmol} / \mathrm{l}){ }^{8}{ }^{9}$ In a study in Bangladesh a hypotonic solution with sodium $67 \mathrm{mmol} / 1$, glucose $89 \mathrm{mmol} / \mathrm{l}$, and osmolarity $249 \mathrm{mmol} / 1$ was compared with the ORS recommended by WHO. In this study the hypotonic ORS performed better than ORS-WHO in rotavirus negative children but not in rotavirus positive children, in whom the hypotonic solution resulted in greater stool output than the ORS-WHO. ${ }^{10}$ In our present study we also made a subgroup analysis for children positive and negative for rotavirus. Our results contrasted with the findings in Bangladesh, as in this study the hypotonic ORS worked particularly well in the patients who were positive for rotavirus (table 4).

Several studies have shown that rice based ORS is at least as effective if not better than the ORS-WHO in correcting dehydration. ${ }^{11}{ }^{12}$ One explanation for this might be the hypotonicity of the starch based solutions. ${ }^{13}{ }^{14}$ A metaanalysis in 1992 concluded that rice based ORS reduces stool output by $18-36 \%$, depending on the age of the patient and aetiology of the diarrhoea. ${ }^{15}$

In conclusion, our study provides further documentation of clinical superiority of low glucose, hypotonic ORS in comparison with high glucose, isotonic ORS, particularly in children with rotavirus associated diarrhoea. While our conclusion is based on studies of 
Table 4 Outcome of patients in subgroups positive or negative for rotavirus, median (min-max) or mean (95\% confidence interval)

\begin{tabular}{|c|c|c|c|c|}
\hline & \multicolumn{2}{|c|}{ Rotavirus positive $(n=40)$} & \multicolumn{2}{|c|}{ Rotavirus negative $(n=21)$} \\
\hline & Hypotonic ORS & Standard ORS & Hypotonic ORS & Standard ORS \\
\hline Median number of diarrhoeal stools in hospital & $8.0(5$ to 38$)$ & 15.0 (2 to 79$)$ & $9.5(2$ to 52$)$ & $13.0(1$ to 20$)$ \\
\hline Mean consumption of ORS during maintenance therapy $(\mathrm{ml} / \mathrm{kg})$ & $76.6(51.7$ to 102$)$ & $115(91.1 \text { to } 140)^{\star}$ & 71.7 (40.4 to 103$)$ & 69.7 (50.8 to 88.7$)$ \\
\hline
\end{tabular}

${ }^{\star} \mathrm{p}=0.038$, two tailed Student's $t$ test; ORS $=$ oral rehydration solution.

children with acute diarrhoea in developed country conditions, the majority of studies done in developing countries are in agreement with our experience and suggest that a reduction in osmolarity of ORS might be generally beneficial and thus desirable.

We thank the nursing staff of the paediatric emergency ward and children's ward No 3 of the Jorvi Hospital for their dedication to children's
this trial.

1 Cunha Ferreira RMC. Optimising oral rehydration solution composition for the children of Europe: clinical trials. Acta composition for the children of Europe:
Paediatr Scand 1989;364(suppl):40-50.

2 Report of an ESPGAN Working Group. Recommendations for composition of oral rehydration solutions for the for composition of oral rehydration solutions for the children

3 Hunt JB, Thillainayagum AV, Salim AFM, Carnaby S, Elliott EJ, Farthing MJG. Water and solute absorption from a new hypotonic oral rehydration solution: evaluation in human and animal perfusion models. Gut 1992;33:1652-9.

4 Sandhu BK, Christobal FL, Brueton MJ. Optimising oral rehydration solution composition in model systems:studies in normal mammalian small intestine. Acta Paediatr Scand 1989;364(suppl): $17-22$.

5 Farthing MJG. Disease-related animal models for optimising oral rehydration solution composition. Acta Paediatr Scand 1989;364(suppl):23-30.

6 Cunha Fereira RCM, Elliott EJ, Watson AJM, Brennan E, Walker-Smith JA, Farthing MJG. Dominant role for osmo- lality in the efficacy of glucose and glycine-containing oral rehydration solutions:studies in a rat model of secretory diarrhoea. Acta Paediatr 1992;81:46-50.

7 Rautanen T, El-Radhi S, Vesikari T. Clinical experience with a hypotonic oral rehydration solution in acute diarrhoea. Acta Paediatr 1993;82:52-4.

8 El-Mougi M, El-Akkad N, Hendawi A, et al. Is a ow-osmolarity ORS solution more efficacious than standard WHO ORS solution? F Pediatr Gastroenterol Nutr 1994; 19:83-6.

9 Bhan MK, Chea Woo E, Fontaine O, Maulen-Radovan I, Pierce NF, Ribeiro H. Multicentre evaluation of reduced$282-5$.

10 Mahalanabis D, Faruque ASG, Hoque SS, Faruque SM. Hypotonic oral rehydration solution in acute diarrhoea: a controlled clinical trial. Acta Paediatr 1995;84:289-93.

11 Islam A, Molla AM, Ahmed MA, et al. Is rice based oral rehydration therapy effective in young infants? Arch Dis Child 1994;71:19-23.

12 El-Mougi M, Hegazi E, Galal O, et al. Controlled clinical trial on the efficacy of rice powder-based oral rehydration solution on the outcome of acute diarrhea in infants. $\mathcal{F}$ Pediatr Gastroenterol Nutr 1988;7:572-6.

13 Farthing MJG. Oral rehydration therapy. Pharmacol Ther 1994;64:477-92.

14 Thillainayagam AV, Carnaby S, Dias J, Clark MI, Farthing MJG. Evidence of a dominant role for low osmolality in the efficacy of cereal-based oral rehydration solutions: studies in a model of secretory diarrhoea. Gut 1993;34:920-5.

15 Gore SM, Fontaine O, Pierce NF. Impact of rice-based oral rehydration solutions on stool output and duration of diarrhoea: a meta-analysis of 13 clinical trials. $B M \mathcal{F}$ 1992;304:287-91.

\section{Cholera phage discovery}

Over the last 120 years or so there have been seven cholera pandemics. Vaccines from killed bacteria do not give lasting immunity and therefore present research is concentrated on live vaccines. A new discovery at Harvard (Matthew K Waldor and John J Mekalanos, Science 1996; 272:1910-4) has important implications for vaccine development as well as for bacterial science (Nigel Williams, Science 1996;272:186970).

Most cholera bacteria are benign but virulent strains can transmit the capacity for toxin production horizontally to other strains. and Waldor and Mekalanos have shown that this transmission is accomplished by a filamentous bacteriophage. A section of DNA within the bacterial chromosome, known as the CTX element, contains at least six genes including the toxin gene and it is this CTX segment which is transmitted by the phage. Toxin production and the formation of bacterial cell surface pili, which are responsible for gut wall adherence, are both regulated by a single bacterial gene, toxR. The CTX-containing phage gains entry to the bacterial cell via the pili which act as receptors; cells without pili are resistant to the phage.

Clearly the potential for horizontal transmission of toxin production is very worrying to vaccine developers but non-pili expressing strains may be safer. (The El Tor strain is less liable to produce pili than are classical strains). Other organisms such as salmonella or yersinia could possibly acquire virulence factors in a similar way. The genetic coregulation of toxin production and pili formation points to the evolutionary interdependence of phage and bacterium working to preserve phage DNA. 